\title{
EQUAL PAY FOR EGUAL WORK IN THE SAME PLACE? ASSESSING THE REVISION TO THE POSTED WORKERS DIRECTIVE
}

\author{
Daniel Carter*
}

\begin{abstract}
Summary: Following criticism of the current system of posted work in the European Union, the Revised Posted Workers Directive 2018/957 was adopted in June 2018. This paper examines the extent to which the Revised Directive is likely to achieve the stated objective, as put forward by the Member States that criticised the current system and as explained in the Commission's original proposal, of ensuring 'equal pay for equal work in the same place'. The article begins by providing a brief overview of posted work within the European Union, including the adoption of the Original D-irective and its interpretation by the Court of Justice. By looking at the key decisions of Laval, Ruffert and Commission v Luxembourg, it explains how the Court's acquis created a system whereby foreign service providers are able to compete unfairly on a national market by circumventing national wage demands in order to gain a competitive advantage, thereby fostering a system of unequal pay for equal work.
\end{abstract}

Following this, the article examines some of the wider implications of the Court's case law. First, it explains how the current system of posted work underlines the normative tension between the ideas of wage competition and social dumping in Europe. Second, it assesses the extent to which the Original Directive acted to deregulate the labour legislation of various Member States, thereby undermining their ability to pursue social policies, as well as their national autonomy. Then, it explains how the Directive is based solely on Treaty provisions relating to service provision and establishment, and what effect this has on the Court's approach to posted workers' cases.

Finally, the article assesses the Revised Directive. It explains the concrete changes to the Directive and then evaluates the extent to which the Revised Directive will achieve the ambition of equal pay for equal work. In this respect, the article claims that the Revised Directive will likely mitigate the more damaging consequences arising from the Court's acquis, although given the more fundamental challenges that exist this may be limited.

\footnotetext{
" Daniel William Carter, LLM, PhD Fellow at Leiden Law School (d.w.carter@law.leidenuniv. nl), https://orcid.org/0000-0001-5443-6932. Many thanks to Vicky Kosta and Ilektra Antonaki for their helpful comments on earlier versions. DOI: 10.3935/cyelp.14.2018.312.
} 


\section{Introduction}

The rise of populism and Euroscepticism throughout Europe brings into focus the extent to which the process of European integration should protect workers from the negative effects of globalisation. The area of posted work is a key example of this, with the Court of Justice coming under fire for 'opening up loopholes meaning companies are able to undercut the going rate in one country by paying the going rate of another'. ${ }^{1}$ Such decisions of the Court, for example the infamous Laval, but also Rüffert and Commission $v$ Luxembourg, ${ }^{2}$ are suggested to have fostered a system whereby foreign service providers are able to compete unfairly with their domestic counterparts on a national market, circumventing wage demands and employment conditions that are applicable to domestic undertakings. More generally, this fits into the wider popular perception that the use of cheap European foreign labour has (rightly or wrongly) negatively affected the wages and working conditions of native populations of older Member States, suggested by French President Emmanuel Macron to be a 'betrayal of the European spirit'. ${ }^{3}$ In June 2015, the governments of Austria, Belgium, France, Germany, Luxembourg, the Netherlands and Sweden wrote to the Commission requesting a proposal for a Revision to the Posted Workers Directive. The core message from the letter, as the Commission states, is that posted workers should receive 'equal pay for equal work in the same place'. ${ }^{4}$ Despite earlier claims that problems associated with the posted workers' system could be most adequately dealt with through enforcement rather than revision, it ultimately agreed with the Member States' assessment. It conceded that the 1996 Directive 'establishes a structural differentiation of wage rules applying to posted and local workers which is the institutional source of an un-level playing field between posting and local companies, as well as of segmentation in the labour market'. ${ }^{5}$ It was also considered

\footnotetext{
1 Jeremy Corbyn, Speech by the Labour Party Leader to the University of Sheffield, Advanced Manufacturing Research Centre (AMRC), 16 June 2016.

2 Case C341/05 Laval ECLI:EU:C:2007:809; Case C-346/06 Rüffert ECLI:EU:C:2008:189; Case C-319/06 Commission v Luxembourg ECLI:EU:C:2008:350.

3 Francois Murphy, 'France's Macron Gains Eastern Foothold on EU Posted Workers' (Thomson Reuters, 23 August 2017) available at <https://uk.reuters.com/article/ uk-france-centraleurope/frances-macron-gains-eastern-foothold-on-eu-posted-workersidUKKCN1B31OG> accessed 27 December 2018.

4 Proposal for a Directive of the European Parliament and the Council amending Directive 96/71/EC of the European Parliament and of the Council of 16 December 1996 concerning the posting of workers in the framework of the provision of services concerning the posting of workers COM (2016) 128 final, 4.

5 European Commission, 'Staff Working Document: Impact Assessment accompanying the document Proposal for a Directive of the European Parliament and the Council amending Directive 96/71/EC concerning the posting of workers in the framework of the provision of services' SWD (2016) 52 final, 10.
} 
that in a number of cases posted workers are being paid significantly less than workers employed by domestic undertakings, thereby facilitating unfair competition and fostering social dumping. ${ }^{6}$

The area of posted work is emblematic of the tension between market and social integration within the European Union. Does the obligation in Article 3 TEU to create an internal market based on a 'highly competitive social market economy, aiming at full employment and social progress' mean anything other than the establishment of a European free market economy ${ }^{7}$ Or does it indicate a desire to create a strong social counterbalance to market considerations, and a commitment that any economic benefits should not be obtained by sacrificing social benefits and society ${ }^{8}$ There exists a normative tension between promoting economic prosperity through transnational service provision, whilst preserving the social protections available to all European workers. Whether the posted workers' system is considered to be the fair use of internal market rules, or social dumping through the undercutting of local employment conditions, is largely a matter of opinion. However, should European integration allow Member States to apply national laws and take measures aimed at ensuring that workers' wages and conditions of employment are not undermined by the use of such internal market rules? Furthermore, does fair competition between domestic and foreign undertakings mean preventing a deregulatory 'race-to-the-bottom', whereby States get locked into a negative spiral as they seek to make themselves more competitive by reducing social standards and protections?

Despite the conflicting interests at stake, and a long-winded adoption process, the Revised Posted Workers Directive 2018/957 has now been adopted by the Parliament and Council. ${ }^{9}$ Following successful trilogue discussions, the European Parliamentary Socialists \& Democrats Group in particular took much pride in the agreed position. ${ }^{10}$ However, just how likely is it that the Revised Directive will realise the stated ambition of 'equal pay for equal work in the same place'? This paper will critically assess the Revision to the Directive, looking at the controversies surrounding the current posted workers regime and the goals the

\footnotetext{
6 ibid, 12-13.

7 TFEU, Art 3(3). See also European Commission Impact Assessment (n 5).

8 Loic Azoulai, 'The Court of Justice and the Social Market Economy' (2008) 45 CMLR 1335, 1337; see also Ilektra Antonaki, 'Collective Redundancies in Greece: AGET Iraklis (2017) 54(5) CMLR 1513.

9 Directive (EU) 2018/957 of the European Parliament and of the Council of 28 June 2018 amending Directive 96/71/EC concerning the posting of workers in the framework of the provision of services [2018] OJ L173/16.

10 Proposal for a Directive (n 4).
} 
Directive sets out to achieve. In order to do this, first there will be a brief account of the history of posted work in the European Union, as well as the adoption of the original Posted Workers Directive and its interpretation by the Court of Justice. Secondly, the paper will examine the wider implications of the Court's approach and criticisms of the posted workers system more generally, as well as the extent to which these are likely to frustrate the realisation of the goal of 'equal pay for equal work in the same place'. Finally, the Revision to the Directive itself will be evaluated, looking at what concrete changes have been made, as well as how it will likely affect the Court's acquis and approach to posted workers' cases and the realisation of the Directive's aims.

\section{Brief introduction to posted workers}

\subsection{The origins of posted workers}

Under private international law (Rome I Convention, now Rome I Regulation), if the applicable law is not chosen within an employment contract, then a worker is subject to the employment conditions of the country where the employee usually carriers out their job: ie where they 'habitually' work, even when temporarily employed in another country. ${ }^{11}$ This means workers sent to another country are, in principle, regulated by the State where the employer's establishment is situated, ie the 'country of origin' principle. ${ }^{12}$ On the other hand, migrant workers in the European Union that move of their own accord to work in another Member State under the provisions on the free movement of workers are immediately entitled to the exact same 'social advantages' as Member State nationals, ie the 'day one' principle, thereby becoming instantly and fully embedded within the host society. ${ }^{13}$

Originally, EU law did not distinguish between workers under the Treaties and those that are now considered as posted workers, ie persons sent by a service provider established in one Member State to carry out

\footnotetext{
11 Regulation (EC) No 593/2008 of the European Parliament and of the Council of 17 June 2008 on the law applicable to contractual obligations (Rome I) [2008] OJ L177/6, Art 8; See also Marc de Vos, 'Free Movement of Workers, Free Movement of Services and the Posted Workers Directive: A Bermuda Triangle for National Labour Standards?' (2006) 7(3) ERA Forum 356, 356.

12 Herwig Verschueren, 'The European Internal Market and Competition between Workers' (2015) 6(2) European Labour Law Journal 137; Stein Evju, 'Revisiting the Posted Workers Directive: Conflict of Laws and Laws in Contrast' (2010) 12 Cambridge Year Book of European Legal Studies 151, 155.

13 Evju (n 12) 155; Verschueren (n 12); Regulation 492/2011 of the European Parliament and of the Council of 5 April 2011 on freedom of movement for workers within the Union [2011] OJ L141/1, Art 7(2).
} 
work temporarily in another. ${ }^{14}$ The Court stated in Commission $v$ France that the application of the Treaty provisions on the free movement of workers should not mean that a Member State's own nationals suffer 'unfavourable consequences' resulting from nationals of other Member States working under conditions of employment or for remuneration less advantageous that those obtained under national law. ${ }^{15}$ In Seco \& Desquenne, which concerned posted workers from a third country (and therefore not covered by the provisions on the free movement of workers), the Court applied this principle by holding that Community law did not preclude Member States from extending their rules on minimum wages to any persons employed within their territory, even temporarily, and regardless of the origin of the employer. ${ }^{16}$

The question of posted workers did not arise until the accession of the Southern Member States in the 1980s. ${ }^{17}$ Rush Portuguesa concerned a contract tender in France. At that time under the Portugal Accession Agreement the provisions on the free movement of workers did not apply to Portuguese workers, who were treated as third country nationals. This was part of the transitional controls imposed upon the accession States due to the divergent wage rates between the old and new Member States. At the same time, however, Portuguese undertakings did benefit from the provisions on services. The question was then to what extent could France apply its national labour legislation to the Portuguese (non-Member State) workers, or whether these workers should be considered as part of the service provider. The Advocate General suggested only including certain types of workers within the undertaking for the purposes of service provision. ${ }^{18}$ However, in a now typical move, the Court took a much stronger economic market integration stance. ${ }^{19}$ It distinguished between posted workers and those falling under the free movement of workers, as posted workers 'return to their country of origin after the completion of their work without at any time gaining access to the labour market of the host Member State'. ${ }^{20}$ With this principle, the

\footnotetext{
14 Jon Erik Dolvik \& Jelle Visser, 'Free Movement, Equal Treatment and Workers' Rights: Can the European Union Solve Its Trilemma of Fundamental Principles?' (2009) 40(6) Industrial Relations Journal 491, 495.

15 Case C-167/73 Commission v France ECLI:EU:C:1974:35, para 45; see also Evju (n 12) 153.

16 Case C-2/81 Seco \& Desquenne ECLI:EU:C:1982:34, para 14.

17 Dolvik \& Visser (n 14) 492.

18 Case C-113/89 Rush Portuguesa v Office national d'immigration ECLI:EU:C:1990:107, Opinion of AG van Gerven.

19 Evju (n 12) 162.

20 Case C-113/89 Rush Portuguesa v Office national d'immigration ECLI:EU:C:1990:142, para 15.
} 
Court effectively established an entirely new legal basis for the (temporary) movement of workers, while at the same time encroaching upon another. ${ }^{21}$ However, in doing so, the Court then went on to effectively extend the Seco principle (which only related to minimum wage rates) to all national labour legislation. It is unclear whether this was simply confused judicial reasoning, or a conscious policy decision intended to appease France and other Member States with strong labour legislation, given the far-reaching implications of establishing a new basis for the movement of workers in the EU. ${ }^{22}$

Effectively, Rush meant that posted workers were not considered to form part of the host country's labour market, and, as such, the entire acquis on workers did not apply to them. By establishing the concept of posted workers, it allowed the circumvention of enlargement transitional controls adopted by most Member States, as there were no controls applying to service providers. ${ }^{23}$ The question of posted workers may never have arisen had Portuguese workers benefited from the free movement of workers provisions at the time. It led to a situation whereby workers could not work on the basis of the free movement of workers, which protects both migrant and native workers by integrating the migrant into the host State to the greatest extent, but could do so as part of a service provider, which offers fewest protections to the worker and commodifies their labour. ${ }^{24}$ That being said, in Rush the Court also handed the Member States 'most of the aces', as they were still potentially permitted to impose all national labour legislation upon foreign services providers and their workers. ${ }^{25}$

In the wake of Rush, Member States applied two main approaches when it comes to extending the labour rights and conditions that are available to native workers. On the one hand, some States (such as France and the UK) extended to all out-of-state services providers national rules on social security, wages, working time, and working conditions (both legislation and collectively agreed). However, other Member States such as Germany introduced more limited legislation, which only applied to the construction industry and only covered minimum wages. ${ }^{26}$ In sub-

\footnotetext{
21 Evju (n 12) 162.

22 Evju (n 12) 163; see Case C-113/89 Rush Portuguesa v Office national d'immigration ECLI:EU:C:1990:142, para 18.

23 de Vos (n 11) 358.

24 Dagmar Schiek, 'Perspectives on Social Citizenship in the EU: From Status Positivus to Status Socialis Activus via Two Forms of Transnational Solidarity' in Dimitry Kochenov (ed), EU Citizenship and Federalism: the Role of Rights (CUP 2015) 355-357.

25 Paul Davies, 'Posted Workers: Single Market or Protection of National Labour Law Systems?' (1997) 34 CMLR 571, 591.

26 ibid, 590.
} 
sequent cases, the Court held that collective agreements could typically be applied, provided they were sufficiently clear, precise, and accessible, and it was possible for the employer to determine his obligations, ${ }^{27}$ and did not discriminate between domestic and foreign undertakings. ${ }^{28}$ Whilst the Court tended to demand that the application of national rules had to be done through 'appropriate means', such application could normally be justified despite the chilling effect upon cross-border service providers..$^{29}$ However, in spite of this, a number of Member States began to become concerned about the application of host-State rules, given the effects of migrant labour from states with much lower wage rates and employment conditions.

\subsection{The original Posted Workers Directive}

The Posted Workers Directive was ultimately the result of a number of failed legislative attempts in the 1970s and 1980s. The 1976 Draft Regulation on the Conflict of Laws pertaining to employment relations within the Community had as its objective equal treatment of all workers and was directed at workers rather than service providers. It maintained the country of origin principle in general, except for a number of specific fields, which are very similar to Article 3(1) PWD. ${ }^{30}$ There was also a proposal for a social clause related to public works in the $1980 \mathrm{~s} .{ }^{31}$ Having failed to secure this, social partners pushed for a more extensive measure applying to the posting of workers generally and based on host-State law from day one. This was supported by a number of Member States that had considered the transitional arrangements to be a letdown, given that the cross-border posting of workers became an easy channel for westward labour migration that circumvented transitional controls. $^{32}$

The Commission made a first proposal for a Posted Workers Directive in 1991, stipulating that the host-State's conditions should apply to core working conditions, including minimum wages. But this was unpopular with a number of Member States, particularly given that Rush Portuguesa meant they had the possibility of applying labour legislation and had little to gain from Community legislation. ${ }^{33}$ The second propos-

\footnotetext{
27 Case C-369/96 Jean-Claude Arblade and Arblade \& Fils SARL ECLI:EU:C:1999:575.

28 Case C-49/89 Finalarte ECLI:EU:C:2001:564.

29 Davies (n 25) 586.

30 Evju (n 12)157-158.

31 Dolvik \& Visser (n 14) 496.

32 ibid, 497; Evju (n 12) 159-160.

33 Jan Cremers, 'The Posting Directive: Origins and Assessment' (1995) 1(2) Transfer: European Review of Labour and Research 309, 309-310; Davies (n 25) 591.
} 
al by the Commission took into consideration more of the prerogatives of the Member States, by reducing the temporal threshold after which Member States must apply their national legislation (France), as well as removing the erga omnes effect of the Directive (Germany), and including Article 3(8) relating to collective agreements (Denmark and Italy). ${ }^{34}$

Given the controversy surrounding the Directive, and in order to avoid the unanimity requirements applying to worker protection issues, the legal bases chosen for the proposal were the freedom of establishment and service provisions. ${ }^{35}$ As the free movement of workers was not a legal base for the original Directive, the Community Charter Fundamental Social Rights of Workers did not apply, and neither did the Treaty provisions in the social field relating to worker protection. Ultimately, the unanimity requirements would have been fatal to the adoption of the Directive. The United Kingdom actually voted against the Directive, considering it on principle to be anti-competitive, whilst Portugal abstained as its undertakings, the main beneficiaries of the posted workers system, stood to lose out. ${ }^{36}$

The shift away from labour law and workers' individual rights towards the rights of service providers 'set the tone' for the framing of the Directive. ${ }^{37}$ The Directive nominally has the dual aims of (i) facilitating the cross-border provision of services by enhancing legal certainty, and (ii) offering protection to posted workers. ${ }^{38}$ Recitals 2 and 3 of the Original Directive emphasise that the internal market creates a dynamic environment' for service provision, and that any restrictions based on nationality or residence are prohibited. Recital 5 indicates that this requires 'a climate of fair competition and measures guaranteeing respect for the rights of workers'. However, as subsequent developments have shown, the promotion of the transnational provision of services is clearly the primary objective, with ensuring fair competition and respect for the rights of workers a distant second. ${ }^{39}$ The 'cornerstone' of the Directive is Article 3(1), which introduces a number of minimum standards that Member States must guarantee, as part of a 'hard core of clearly defined protective rules'. ${ }^{40}$ These must be laid down either by 'law, regulation or administrative provision', or by 'collective agreements or arbitration

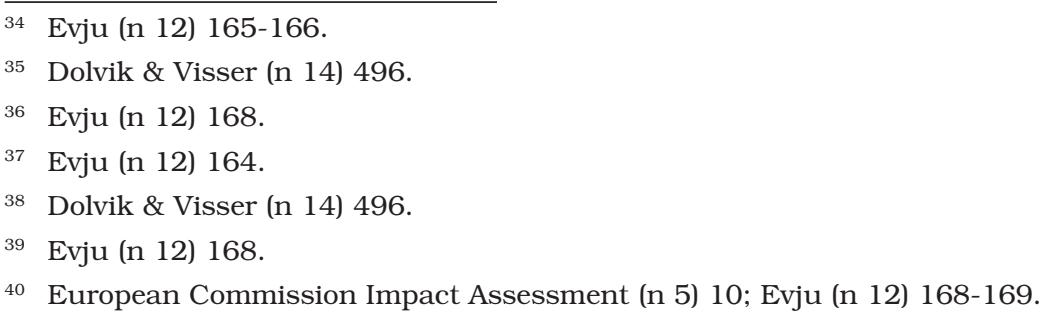


awards which have been declared universally applicable'. In particular, Article 3(1)(c) refers to 'minimum rates of pay, including overtime rates'.

\subsection{Interpreting the Posted Workers Directive}

Even at the time of the Directive's adoption, there was uncertainty over its precise scope and value. Would the promotion of the cross-border provision of services be reconciled with the acceptance that labour regulations perform a legitimate function in protecting the weaker party within a contractual relationship, or would the Court take the view that Rush Portuguesa 'trenches too far' upon the Treaty rights of service providers $?^{41}$ In this section, three decisions will be examined, namely those of Laval, Rüffert, and Commission v Luxembourg, to demonstrate how the Court interpreted Article 3(1), in particular the rules of pay, and how these interpretations led to the criticisms of the posted workers regime that have ultimately led to the Revision to the Directive.

Laval concerned a Latvian company that posted workers to Sweden in order to construct a school extension. There was an expectation that Laval would apply the Swedish national collective agreement to its own posted workers, which at the time was predominantly negotiated between management and workers within a company on a case-by-case basis. The Swedish trade union included within the collective agreement an obligation on Laval to pay its workers approximately 16 per hour. ${ }^{42}$ Laval offered around half this rate, along with some additional benefits, claiming that signing the collective agreement meant that they would not know what wages it would have to pay (it is not clear why Laval could not look at previous wage increases and/or rates of inflation, as did the trade union when making the wage demands). The trade union decided to take strike action, and was soon followed by sympathy strike protests. Laval then complained that the trade union's action violated Article 56 TFEU. The Court determined that Article 3(1) only relates to minimum rates of pay. As the conditions the trade union sought were not minimum wages under either Article 3(1) or (8) of the Directive, it was held that they fell outside its scope. ${ }^{43}$ It then proceeded to determine that the trade union's actions in trying to enforce the Swedish rule were an unjustifiable restriction on the Treaty provisions on the freedom to provide services.

Rüffert concerned a public tender contract awarded by Lower Saxony. Within its system of public procurement, Lower Saxony had a rule that obliged public authorities to award contracts or building works only

41 Davies (n 25) 573-574; 596-598.

42 Laval (n 2) paras 30-31.

43 Laval (n 2) para 70. 
to undertakings paying wages laid down in the local collective agreement. As the company committed to pay its employees only around half of what was in applicable collective agreements, Lower Saxony fined Rüffert. The company challenged the decision on the basis that Article 56 TFEU precludes a statutory obligation to pay employees wages in collective agreements applicable to the public sector. The Court decided that the rules could not be considered as a 'law' under Article 3(1) of the Directive because it does not fix any minimum rates of pay itself. Furthermore, the collective agreements had not been declared universally applicable in accordance with the Directive. The first paragraph of Article 3(8) could not apply, as Germany did have a system for declaring collective agreements universally applicable (this only applies when there is no system for doing this at all). It could also not fall under the second paragraph of Article 3(8) as the agreement was not generally applicable to all similar undertakings in the geographical area and in the profession or industry concerned. ${ }^{44}$ Moreover, the Court agreed with the Commission that the Lower Saxony rules discriminated between the private and public sectors, given that the collective agreement only applies to construction workers in the public sector. ${ }^{45}$ The Court also confirmed that cross-border services cannot be made conditional upon conditions that '...go beyond the mandatory rules for minimum protection'. ${ }^{46}$ This meant that the State could not rely on the Directive, and the Court found that the measure was 'an additional economic burden that may prohibit, impede or render less attractive the provision of their services in the host Member State. ${ }^{47}$ The Court then went on to use the same reasoning to find that the measure could not be justified.

Finally, Commission v Luxembourg concerned the Commission's infringement proceedings against Luxembourg for a number of national rules relating to the Posted Workers Directive. Luxembourg had argued that, even if the national rules were not covered under Article 3(1), then the exception contained in Article 3(10) which states that the Directive shall not apply to conditions of employment outside Article 3(1) in the case of public policy provisions' should apply. In particular, two complaints are important: the automatic adjustment of wage rates in order to meet the costs of living, and rules relating to collective agreements. In terms of the automatic cost-of-living adjustments, the Court held that the Community legislature intended to limit the possibility of Member States intervening as regards pay. As such, any measures relating to

\footnotetext{
44 Rüffert (n 2) para 39.

45 ibid, paras 39-40.

46 ibid, para 33.

47 ibid, para 37.
} 
the automatic adjustments of rates of pay other than the minimum wage would fall outside the scope of Article 3(1). ${ }^{48}$ As regards the public policy exception, the Court used the terminology of the Rome I Regulation to hold that this must be deemed 'so crucial for the protection of the political, social, or economic order' of the Member State concerned so as to require compliance by all persons in that State, and should furthermore be interpreted restrictively. ${ }^{49}$ The Court considered that Luxembourg had failed to submit 'appropriate evidence of the expediency and proportionality of the restrictive measure', ${ }^{50}$ and as such found that it could not rely on Article 3(10). The Court also held that the rules on collective agreements could not fall under the public policy exception, as these need to be declared universally applicable, which was not the case. ${ }^{51}$

\subsection{Evaluating the Court's approach to posted workers}

The Court has been criticised for focusing too much on the Directive's primary objective of facilitating service provision and not enough on the nominal objective of ensuring fair competition and protecting workers. Most pertinently, Member States cannot impose labour legislation that goes beyond what is listed in Article 3(1), going some way to reviving the country of origin principle, ${ }^{52}$ particularly in the case of wage demands that are not the legislated minimum wage in the host State. In fact, outside the 'hard nucleus' contained in Article 3(1), the country of origin continues to apply. ${ }^{53}$ Article $3(1)$ should therefore not been seen as setting minimum standards, but rather a conflict of laws provision which allows posted workers to rely on the basic standards listed, which prevail over Articles 4 and 8 of the Rome Regulation. ${ }^{54}$ This means that in a number of situations, labour standards of low-cost home States can be directly translated on to the territory of the host State in what Deakin describes as 'a form of legally mandated social arbitrage in which labour law regimes are placed in direct competition with each other. ${ }^{55}$ By applying the market-access Säger approach, which focuses on the effect of the national measure on the market access of out-of-state actors and ignores

48 Case C-319/06 Commission v Luxembourg ECLI:EU:C:2008:350, para 47.

49 ibid, paras 29-30; see Regulation No 593/2008 (n 11) Art 9.

50 Commission v Luxembourg (n 48) para 51.

51 ibid, para 67.

52 Simon Deakin, 'Regulatory Competition in European after Laval' (2008) Centre for Business Research Working Paper No 364, University of Cambridge, 6.

53 Dolvik \& Visser (n 14) 497.

54 Evju (n 12)168-169.

55 Deakin (n 52) 15. 
the negative effects it may have on in-state actors, ${ }^{56}$ the Court commits to what can be described as a 'highly deregulatory principle'. ${ }^{57}$ Furthermore, the Court's approach means that Directive 96/71 and Article 56 TFEU are mutually reinforcing: measures that fall outside the Directive for going beyond its mandatory rules in Article 3(1) will be found to be disproportionate precisely because they fall outside the Directive. Lastly, the Court's interpretation of Article 3(10) means that very little, if anything, can be justified under the public policy exception contained therein.

\subsubsection{Laval}

The absence of a legislated minimum wage or a system of declaring collective agreements universally applicable in Laval means that there is simply no minimum rate of pay within the Swedish system, and thus Article 3(1)(c) offers no protection. The Court's reasoning revolves entirely around the fact that under Directive 96/71 employers are required 'to observe a nucleus of mandatory rules for minimum protection in the host State. ${ }^{58}$ This means that an obligation to pay a certain wage (arguably any wage) would therefore always be disproportionate. Any demands by Member States or their social partners that undertakings pay more than the minimum rate of pay is therefore a violation of Article 56 TFEU and must in principle be justified. However, as the Directive lays down both the minimum and maximum wage demands that can be imposed under service providers, ie it fully harmonises wage rates applicable to foreign service providers, ${ }^{59}$ this means that any measure falling outside the Directive will also be disproportionate. Laval also places excessive emphasis on formal legislated minimum rates of pay at the expense of other looser forms of wage agreement. Collective autonomy was 'too messy, too uncertain, too disruptive' compared to judicially enforced legislation as a means of setting and protecting standards for posted workers. ${ }^{60}$ This undermines the Court's claim that Member States are free to choose a system of wage negotiation outside those permitted under the Directive. ${ }^{61}$ Lastly, it is even suggested that the situation in Laval does not actually impose any additional costs upon Laval which made it more difficult to

\footnotetext{
56 Catherine Barnard, 'A Proportionate Response to Proportionality in the Field of Collective Action' (2012) 37(2) EL Rev 118; see Case C-76/90 Säger ECLI:EU:C:1991:331.

57 Catherine Barnard, 'Posted Workers: Single Market or Protection of National Labour Law Systems?' (1997) 34 CMLR 571, 588.

58 Laval (n 2) para 108.

59 Barnard (n 56); Evju (n 12) 171, 175; Deakin (n 52) 4.

60 Claire Kilpatrick, 'Laval's Regulatory Conundrum: Collective Standard-Setting and the Court's New Approach to Posted Workers' (2009) EL Rev 844, 856.

${ }_{61}$ Laval (n 2) para 68; Kilpatrick (n 60) 852.
} 
operate in Sweden, at least when compared to the costs that would have been incurred had the Swedish rule not existed, or even in comparison to Swedish undertakings. ${ }^{62}$

The Court had alternative interpretations of the Directive available to it. It could have interpreted Article 3(1) less as a conflict of laws rule, and more as a floor of minimum rights. This would mean that in the absence of any minimum rate of pay in Swedish law, at least its wage negotiation legislation could be applied. This would also be the widely accepted understanding of how other directives and regulations function, which seek to establish a floor of rights above which regulatory competition is possible. ${ }^{63}$ The Court could still have conditioned the application of the national rule on the basis that it is done through 'appropriate means'. Alternatively, more focus could be placed on the unequal treatment occurring between service providers, rather than simply looking at their market access. This was the approach of Advocate General Mengozzi in his Opinion. ${ }^{64}$ AG Mengozzi considered that the aim of Article 3(1), besides creating minimum standards, is to ensure that there is equal treatment between service providers. Moreover, he believed that the Swedish legislation in question guarantees trade unions the opportunity to impose wage conditions laid down or governed by Swedish collective agreements, ${ }^{65}$ meaning that the rates included within such collective agreements are, at least indirectly, legislated for. The Court demonstrated a strong reluctance to allow pay determined in Swedish collective agreements, or indeed any case-by-case agreement, to be considered as a 'minimum' rather than simply the going rate for the job, potentially undermining the commitment not to protect national systems of wage setting.

\subsubsection{Rüffert}

The Rüffert decision suggests that in the context of public procurement, foreign service providers can circumvent wage demands that are applicable to domestic undertakings. In fact, the Court explicitly stated that the Lower Saxony rule would result in foreign undertakings losing 'the competitive advantage which they enjoy by reason of their lower wage costs'. ${ }^{66}$ This means that any demand going beyond Article 3(1) will result in the foreign service provider losing their competitive advantage

62 Deakin (n 52) 4.

63 ibid, 14.

64 Case C341/05 Laval ECLI:EU:C:2007:291, Opinion of AG Mengozzi, para 171.

65 ibid, para 185.

66 Ruffert (n 2) para 14. 
and thereby falling outside its scope, confirming the minimum / maximum principle in Laval. ${ }^{67}$ The decision also narrows the specific types of collective agreements that Article 3(1) can apply to. The Directive is supposed to allow for different types of collective agreements; however, it is clear that differentiating between public sector and private sector wage rates is not possible - despite the fact that a local authority is unable to set private sector wage rates. Locally agreed public sector collective agreements, typical in many Member States, are therefore discriminatory under the Directive. ${ }^{68}$ This would also likely be the case with non-binding obligations to pay a 'living wage', if this goes above the legislated minimum wage.

Similarly to Laval, the Advocate General in Rüffert came to the opposite conclusion to the Court, using an entirely different approach. For AG Bot, the only important consideration was whether the rules complied with the principle of non-discrimination on the basis of nationality. As such, service providers would be subject to the same obligation relating to rates of (minimum) pay applicable to the location where the services were being performed. ${ }^{69} \mathrm{He}$ also considered that Article 3(7) of the Directive permits in principle '...the implementation of enhanced national protection', meaning that Member States should be entitled to demand a higher rate of pay when it concerns public contracts that improve the level of social protection. ${ }^{70}$ However, such enhanced national protection must comply with Article 56 TFEU. Finally, he also considered that the 'social objectives' contained in the 2004 Public Procurement Directive would allow such wage demands, a point which the Court curiously omitted entirely, given the subject matter of the case.

\subsubsection{Commission v Luxembourg}

Finally, the Commission $v$ Luxembourg decision means that virtually any measure that goes beyond Article 3(1) cannot be justified using the public policy exception in Article 3(10). Yet again, this went against the Opinion of the Advocate General, who considered that the automatic adjustment of pay in line with cost of living changes actually fulfilled the requirements of Article 3(1)(c) of the Directive. ${ }^{71}$ However, the Court did not agree, and created an incredibly stringent test based on Article 9 of

67 Vasiliki Kosta, Fundamental Rights in EU Internal Market Legislation (Bloomsbury 2015) 203.

68 Kilpatrick (n 60) 848.

69 Case C346/06 Rüffert ECLI:EU:C:2007:541, Opinion of AG Bot, para 131.

70 ibid, para 83.

71 Case C-319/06 Commission v Luxembourg ECLI:EU:C:2007:516, Opinion of AG Trstenjak, para 54 . 
the Rome I Regulation, which makes it effectively impossible to establish except in exceptional circumstances, for example the prohibition of slavery. ${ }^{72}$ In both Laval and Rüffert, the Court employed circular reasoning to find that measures falling outside the scope of the Directive cannot be justified on the basis of Article 56 TFEU because it goes beyond the conditions laid down in Article 3(1). The Court did not follow the Advocate General's consideration in Laval that the law in question was an appropriate and necessary means of preventing social dumping. ${ }^{73}$ Furthermore, in Rüffert, unlike the Advocate General, the Court considered that Article 3(7) could not be considered as allowing for 'enhanced national protection', as it would allow Member States to impose terms and conditions of employment beyond the minimum protection contained in Article 3(1). ${ }^{74}$ When combined with the stringent test imposed under the public policy exception contained in Article 3(10), justification in the area of posted workers seems almost impossible.

\subsection{Conclusion: unequal pay for equal work?}

The Court's approach to interpreting the Directive has arguably been most liberal for service providers and most restrictive for Member States and social partners. Despite the Directive's clear social objective, following the Court's Laval case law 'the economic has taken precedence over the social', with the objectives of fair competition and respect for the rights of workers clearly secondary to the promotion of the transnational provision of services. ${ }^{75}$ In particular, the Court's approach to interpreting Article 3(1) of the Directive as a conflict of laws instrument instead of a minimum floor of rights, as well as the extremely limited possibility of justifying either under Article 3(10) of the Directive or Article 56 TFEU directly, suggests that there are three situations in which foreign service providers can circumvent wage demands applicable to domestic undertakings, thereby fostering a system of unequal pay for equal work. First, where there is no minimum rate of pay due to the system of industrial relations in the host Member State, a foreign service provider can pay its posted workers below the collectively agreed rate in that sector. There is

\footnotetext{
72 Commission v Luxembourg (n 48) para 29; Louise Merrett, 'Posted Workers in Europe from a Private International Law Perspective' (2011) 13 Cambridge Year Book of European Legal Studies 219, 233; Dolvik \& Visser (n 14) 502-503. See also Catherine Barnard, 'The UK and Posted Workers: The Effect of Commission v Luxembourg on the Territorial Application of British Labour Law' (2009) 38 Industrial Law Journal 122.

73 Rüffert ( $n$ 69) paras 119, 122. The Court did not even discuss the justification of combatting social dumping.

74 Rüffert (n 2) para 33.

75 Evju (n 12) 168-170. See also Catherine Barnard, 'Social Dumping or Dumping Socialism' (2008) 67(2) Cambridge Law Journal 262; Cremers (n 33).
} 
no obligation under Article 3(1)(c) to pay the minimum rate of pay simply because there is no minimum rate of pay. As was the case with Sweden, Member States are forced either to change their systems of industrial relations or accept a system that fosters unfair competition by paying wages below those applicable to domestic undertakings. Secondly, if there is a system for declaring collective agreements universally applicable, then any wage demands going beyond this will not be covered by the Directive. Even if it is effectively impossible to declare these agreements universally applicable (for example, they only apply to public sector contracts), then this again will fall outside the scope of the Directive. Foreign service providers are thus able to actively use differences in obligations between domestic and foreign undertakings to gain an advantage on a national market whilst Member States simply cannot force them to pay the same rate as would be applicable to domestic undertakings. Thirdly, even if there is a legislated minimum wage in the country in question, the Court's approach to interpreting Article 3(1)(c) means that this can become the maximum that a Member State can demand from a foreign service provider. As the Commission has noted, often the "minimum rate of pay' for a specific job is interpreted as meaning a 'minimum legislated wage ${ }^{76}{ }^{76}$ suggesting that protection is unnecessary where it goes beyond the lowest level provided by law in the host State. ${ }^{77}$ It is suggested that the Court may find that no space exists for a second and higher minimum pay rate set collectively. Indeed, even collective action to enforce statutory minimum wages would be found to be disproportionate if other methods of enforcement were available. ${ }^{78}$ Finally, if a measure is found to fall outside Article 3(1), there are very limited possibilities to justify this under either Article 3(10) of the Directive, or Article 56 TFEU.

\section{Realising 'equal pay for equal work in the same place'}

After having examined the Court's approach to interpreting the Posted Workers Directive, the following section will claim that the Court's approach (and system of posted work more generally) has three key implications that are liable to frustrate the realisation of the aim of 'equal pay for equal work in the same work'. In this respect, it will be suggested that the Court's approach (i) strikes at the heart of the normative tension between the concepts of social dumping and competition on the basis of wages; (ii) emphasises the deregulatory nature of the Directive and European integration in general; and (iii) highlights the 'market-bias' (ie the lack of social considerations) built into the Directive itself.

\footnotetext{
${ }_{76}$ European Commission Impact Assessment (n 5) 11.

77 Deakin (n 52) 17.

78 Kilpatrick (n 60) 854-856.
} 


\subsection{Social dumping \& wage competition}

The first issue is the normative distinction between when the use of posted workers is the fair use of internal market rules to gain a competitive advantage against one's competitors, and when it illegitimately undercuts local wages and employment standards, thereby resulting in what might be considered as 'social dumping'. The Court has emphasised that preventing unfair competition, protecting workers, and combatting social dumping are all valid (and often interlinked) objectives that can potentially justify a restriction to free movement. ${ }^{79}$ Battling social dumping is also suggested to be a key factor behind the revision to the Directive. ${ }^{80}$ However, concretely defining this concept, particularly in the context of posted workers, is extremely difficult. The term tends to be thrown around by those seeking to use it to their own ends, which can result in inconsistent and ill-grounded perceptions. ${ }^{81}$ Definitions such as the 'application of different wages and social protection rules', ${ }^{82}$ or 'undermining or evading existing social regulations with the aim of gaining competitive advantage', ${ }^{83}$ tend to omit the fact that the application of different wages and social protection rules forms the basis of the competition in which undertakings (and Member States) engage in order to sell products and enter new markets.

It should also be emphasised that competition in terms of labour costs and wages is something that happens in every sector and in every jurisdiction, and is no more a source of unfair competition or social dumping than it is within national markets. Lower paid workers may produce cheaper goods in other Member States, and yet these goods cannot be excluded from national markets merely because they have been produced using labour costs and standards from a State where these are lower. ${ }^{84}$ Allowing Member States to exploit their full comparative advantage and giving companies the chance to restructure their activity

\footnotetext{
79 See Case C244/04 Commission v Germany ECLI:EU:C:2006:49, paras 57, 61; Laval (n 2) para 103; Laval (n 64) para 249; Rüffert (n 69) paras 114-122; Case C-549/13 Bundesdruckerei ECLI:EU:C:2014:2235, para 31.

80 Silvia Pelz, 'S\&Ds Score Important Victory for European Workers: Equal Pay for Equal Work in the Same Place Now within Reach' (S\&D, March 2018) available at <www.socialistsanddemocrats.eu/newsroom/sds-score-important-victory-european-workers-equalpay-equal-work-same-place-now-within> accessed 22 December 2018.

81 Magdalena Bernaciak, 'Social Dumping and the European Integration Process' (2014) European Trade Union Institute Working Paper 2014.06.

82 See European Parliament Briefing, 'Understanding Social Dumping in the European Union' (March 2017) available at <www.europarl.europa.eu/RegData/etudes/ BRIE/2017/599353/EPRS_BRI(2017)599353_EN.pdf> accessed 22 December 2018.

83 Bernaciak (n 81) 5.

84 Davies (n 25) 598.
} 
on a pan-European scale is suggested to improve the attractiveness of Europe as a whole as a place to create wealth and employment. ${ }^{85}$ What might legitimately be considered as 'unfairly' competing on the market through the use of differing labour costs and standards between regulatory regimes can therefore also be seen as the smooth functioning of the internal market and the use of various competitive advantages, which will lead to overall efficiencies. ${ }^{86}$ However, the drive for efficiencies and competitiveness between Member States has meant increased competition in all areas, with labour costs being a core aspect of this. ${ }^{87}$

Moreover, it is suggested that linking social dumping directly with the higher standards in Western Member States is 'Western-centric, arbitrary and normative'. ${ }^{88}$ However, this surely overlooks the point that social dumping can only ever be seen as from the perspective of those that are negatively affected by it. Imposing the legislation of high-regulation States may be Western-centric, but there is nothing to stop Eastern States adopting and applying higher standards should they so wish. Indeed, the idea of 'upward convergence' suggests that European integration should encourage newer Member States to 'catch up' with their traditional counterparts by improving wages, social rights, and protections at a greater rate. ${ }^{89}$ Whilst accession States, in particular the ex-Soviet bloc, were encouraged to join the internal market precisely because they would have a competitive advantage in relation to the established western and northern Member States, this advantage is not envisaged to be permanent. It will be interesting to see if in some years' time Member States such as Poland will be making the same pro-competition arguments against the Balkan States, who will have likely joined the EU by then, when it is they who are the high-wage States trying to protect their citizens from the negative effects of regulatory competition and social dumping. In any event, the current dynamic is likely to result in pressures being placed on both high-wage and low-wage States to either actively reduce wage rates and employment standards, or at least where there is little incentive to raise them. In its Impact Assessment to the Revised Directive, the European Commission already conceded the pressures the posted workers' regime can place on wages in some sectors.

\footnotetext{
85 Andre Sapir, 'Globalisation and the Reform of European Social Models' (2005) Bruegel Policy Paper 4 available at <http://bruegel.org/wp-content/uploads/imported/publications/pc_sept2005_socialmod.pdf> accessed 22 December 2018.

86 Daniel Vaughan-Whitehead, EU Enlargement versus Social Europe? The Uncertain Future of the European Social Model (Edward Elgar Publishing 2003).

87 European Commission Impact Assessment (n 5) 4.

88 Bernaciak (n 81) 8.

89 See European Parliament Report on Social Dumping in the European Union (2015) A80255/2016.
} 
However, whether the use of these kinds of comparative advantages on the basis of wage competition is viewed as creating efficiencies in the internal market, or condemned as social dumping, is therefore largely a normative question that tends to be based mostly on one's perspective. ${ }^{90}$ Simply put, one person's social dumping is another's competitive advantage. But whilst there may be improvements in innovation, efficiencies, and productivity, pressures are also placed on wages and employment conditions. More focus is placed by EU institutions on the market and on ensuring free competition as the 'general solution' to Europe's problems, ${ }^{91}$ a claim which could be equally directed at the Commission and the Court of Justice, at least in the context of posted workers.

This is not to say that competition on the basis of wages is unproblematic, as was suggested around the time of the adoption of the original Posted Workers Directive. The idea that competition from workers whose wages are lower or that other terms and conditions of employment are less advantageous is necessarily unfair to workers from higher-regulation States was claimed to be 'surely erroneous', and that wage competition does not necessarily lead to lower prices, as other factors such as productivity play a more important role. ${ }^{92}$ Whilst this is true to a certain extent, the idea that labour costs do not have an effect on wages is surely also erroneous, particularly when undertakings are competing for the performance of a works contract or public tender, rather than, for example, German or Danish goods competing with cheaper products in other Member States where consumers' preferences are likely to be based on more than simply price. In terms of posted workers, it is suggested that they themselves benefit from the current arrangement, and that accusations of diminished social rights in receiving countries can just as easily be framed in terms of the gained social rights of workers in sending countries. ${ }^{93}$ Barnard tentatively agrees, suggesting that 'opening up the markets will benefit ... workers, improving their prosperity'. ${ }^{94}$ However, if (for example) Swedish workers are replaced by those from Latvia precisely because they will work for lower wages and worse conditions than the Swedish workers, whose social rights have actually been improved? The fact the Latvian company won a contract certainly could result in

\footnotetext{
90 Catherine Barnard, 'Social Dumping and the Race to the Bottom: Some Lessons for the European Union from Delaware?' (2000) 25(1) EL Rev 57, 68.

91 Fritz Scharpf, 'Why the European Union Cannot Be a Social Market Economy' (2010) 8(2) Socio-Economic Review 211, 225.

92 Davies (n 25) 598-599.

93 See Barnard (n 56) 123. Barnard makes the point in response to a claim by D Kukovec in 'Whose Social Europe?' available at <https://papers.ssrn.com/sol3/papers.cfm?abstract_ id $=1800922>$ accessed 22 December 2018.

94 Barnard (n 56) 123.
} 
greater economic growth, which itself could in turn result in higher wages and employment conditions being provided to Latvian workers, but this is in no way guaranteed. On the other hand, the Swedish workers have lost their employment and may face future pressures on wage rates and employment conditions. Moreover, those losing their jobs in traditional economic activities as a result of these competitive advantages have little chance of finding employment elsewhere. For them, competition from newer Member States becomes a zero-sum game, whereby their prospects (or lack thereof) are in direct competition with persons from newer Member States. ${ }^{95}$ Lastly, even from the perspective of the migrant worker, does exercising free movement rights necessarily result in the migrant 'benefiting' from the arrangement? If companies seek to recruit exclusively from low-wage countries precisely because they will put up with conditions unacceptable to native workers, and are furthermore less likely to challenge them through collective action or political engagement, which workers actually benefit from this situation? ${ }^{96}$

In the context of posted workers, a distinction must therefore be made between competition on the basis of labour costs between undertakings in different regulatory regimes when compared to the situation of undertakings competing within the same jurisdiction. The application of differing wage rates and social protection rules can be used directly to outbid a domestic rival due to differences in labour costs, or otherwise put pressures on wages, leading to a race to the bottom. This can be referred to as a kind of regulatory arbitrage in which the undertaking can follow European rules but choose to remain partially outside the national industrial framework of the host country, ${ }^{97}$ often at the direct expense of workers in that country, and arguably the posted workers themselves. It can be concluded that it is when service providers compete on the basis of wage costs by using different state regulations to compete within the same jurisdiction that this fosters unfair competition and contributes to social dumping. The Directive, with its focus on parity of pay when work is performed in the same location, seeks to resolve this normative tension. Lastly, it should be noted that this parity of pay does not require the effective elimination of wage competition in the field of service

\footnotetext{
95 Sapir (n 85) 4; Schiek (n 24) 355.

96 On this point, see the fascinating account of James Bloodworth, Hired: Six Months Undercover in Low-Wage Britain (Atlantic Books 2018). Particularly Part 1 which deals with the experience of working at the Amazon warehouse in Rugeley, England; see also Schiek (n 24) 364-365.

97 Lisa Berntsen and Nathan Lillie, 'Breaking the Law? Varieties of Social Dumping in a pan-European Labour Market' in M Bernaciak, Market Expansion and Social Dumping in Europe (Routledge 2015) 55.
} 
provision. ${ }^{98}$ Undertakings will still compete on the basis of labour costs generally: this is still an essential component of competition. Rather, any advantage gained in this respect should not simply be because an undertaking is established in another Member State. Likewise, foreign undertakings can still use their place of establishment in order to gain an advantage over domestic undertakings, but wage rates in the host State should not be basis for this advantage.

\subsection{Deregulation and posted work}

The second critique of the Posted Workers Directive is that it has acted as a tool of deregulation. This is an argument not limited to the area of service provision and posted work. There is long-standing criticism, most forcefully put forward by Scharpf, 99 that the structural bias at the heart of European integration means that it has a liberalising effect on Member State legal systems, removing flexibility in terms of the varied forms of market economies in the European Union, and converging towards a 'European' ideal of a liberal market economy. In the context of posted work, this effectively means that Member States are prohibited from imposing their own higher wage rates and labour standards if they go beyond the 'European' ideal of what these should be. As the case law of the Court has shown, it is skewed towards finding national legislation enforcing higher domestic wages as restricting the free movement rights of foreign undertakings at the expense of national legislation.

The European Communities were originally based on the 'Polanyian compromise' of embedded liberalism, whereby measures aimed at freeing and liberalising the market (particularly in the case of the movement of persons) must be 'embedded' in the social norms, laws and policies that remain the exclusive right of national States. ${ }^{100}$ Indeed, the idea of Europe-wide labour standards was dismissed in the Spaak report. Instead, it was considered that currency devaluations would adequately allow for the elimination of distortions in wage costs, which were considered to happen only if undertakings were able to tap into a pool of low-cost labour

\footnotetext{
98 Kosta (n 67) 197; see also de Vos (n 11) 357.

99 Scharpf (n 91); see also Fritz Scharpf 'After the Crash: A Perspective on Multilevel European Democracy' (2015) 21(3) European Law Journal 384.

100 Verschueren (n 12) 130. See also, Matthias Goldmann, 'The Great Recurrence: Karl Polanyi and the Crises of the European Union' (2017) 23 European Law Journal 272; Diamond Ashiagbor, 'Unravelling the Embedded Liberal Bargain: Labour and Social Welfare Law in the Context of EU Market Integration' (2013) 19(3) European Law Journal 303; John Ruggie, 'International Regimes, Transactions and Change: Embedded Liberalism in the Postwar Economic Order' (1982) 36(2) International Organisation 379; see also Karl Polanyi, The Great Transformation: The Political and Economic Origins of Our Time (Beacon Publishing 1947).
} 
which was not open to firms based elsewhere. This original compromise was not drastically changed by the series of directives and regulations in the labour law field in the 1970s and 1980s, as these only touched upon a small area of topics and set 'floors' not 'ceilings', allowing for plenty of discretion by Member States. However, this delicate balance is suggested to no longer apply. A variety of factors, such as negative integration, QMV voting, and mutual recognition, have created a structural bias which results in a process of deregulation, and a lowest-common-denominator approach to social protection. Nominal labour costs are no longer closely aligned across the Union, and currency devaluations are no longer possible within the Eurozone, with 'internal devaluation' by reducing labour costs being the main tool to regain competitiveness. ${ }^{101}$

Social legislation comes under pressure from integration through law, as national rules are increasingly viewed as simply an obstacle to the exercise of free movement provisions. ${ }^{102}$ Moreover, mutual recognition often means that host-State regulation, such as labour law, is incompatible with internal market provisions, and there are few possibilities for derogations. Cases are usually brought by parties that have an economic or personal stake in increasing mobility and deregulation, and the financial resources to do so, often at the expense of the less mobile majority or those representing the interests of workers. All these factors mean that the law, independent of any liberal-based ideological preference, will still be driven towards liberalisation, if only through searching for new obstacles to trade to remove. Moreover, the decisions of the Court can only have a deregulatory effect on Member States, and cannot adopt common European rules that substitute disapplied national regulations. Harmonisation at the European level is hampered by the requirement to find consensus among Member States, given their diverse preferences and prerogatives. When adopting harmonising measures, the Court's decisions gain a constitutional status that becomes the basis for future legislation, and any more radical suggestions are likely to be watered down or vetoed by a liberal Member State. ${ }^{103}$

These factors will affect different types of economies in different ways. Scharpf makes the distinction between 'Liberal Market Economies' ('LMEs', such as the UK and to some extent the Netherlands) on the one hand, and 'Coordinated Market Economies' ('CMEs', which he attributes to Continental European and Scandinavian countries) on the other, a distinction broadly along the lines of Esping-Andersen's distinctions in

\footnotetext{
101 Deakin (n 52) 19-20.

102 Verschueren (n 12) 130.

103 Scharpf (n 91) 227.
} 
terms of the 'worlds' of capitalism. ${ }^{104}$ Generally speaking, LMEs sets the preconditions of a functioning market by protecting property rights, enforcing private contracts and ensuring a regime of undistorted competition. By their very nature, they will be relatively unaffected by deregulatory decisions of the Court and in fact often profit from the removal of non-tariff barriers in other Member States. On the other side, CMEs create highly regulated and inflexible labour markets, with relations shaped by cooperative collective bargaining and interactions embedded in relatively stable network relationships, ${ }^{105}$ and are extremely vulnerable to the deregulatory effects of negative integration. Only high regulation States need to be concerned about their national laws being struck down, as Member State economies converge towards a Europeanised ideal liberal market economy. This convergence is based on a fallacious vertical relationship between the EU and the 'Member States', as if they were a homogenous collective bloc to which all rules apply equally. Instead, the divergent socio-cultural concerns between States are often at the very root of normative tension and political dissatisfaction generated by the recent progress of legal integration. ${ }^{106}$ The solution to this is re-regulation through secondary legislation at the European level, although the high consensus requirements generally favour status-quo positions, which tend to be in line with liberal market economies.

Turning to posted workers, the decisions of the Court of Justice clearly undermine the ability of CME Member States to apply their national legislation. In Laval, the Swedish CME rules on wage bargaining were in conflict with the European LME-style rules on minimum rates of pay. Rather than mitigating the deregulatory effects of integration through law, the Court's approach to interpreting Article 3(1), when combined with the circular and self-reinforcing relationship between Article 56 TFEU and the Directive, means that its application deregulates in much the same way as negative integration through primary law. ${ }^{107}$ This undermines the ability of Member States to pursue CME policies, as well as national autonomy and diversity. For example, Laval did not affect the vast majority of Member States, as they did not have Swedish-style systems of wage bargaining. However, the rules provoked major normative difficulty in Sweden, which had to amend national laws on wage calculation which had been in place since the 1930 s. ${ }^{108}$ To meet

\footnotetext{
104 Gosta Esping-Andersen, The Three Worlds of Welfare Capitalism (Blackwell 1990). See also Peter Hall \& David Soskice, The Varieties of Capitalism: The Institutional Foundations of Comparative Advantage (OUP 2001).

105 Scharpf (n 91) 234.

106 Scharpf (n 91) 239-240.

107 Barnard (n 72) 123.

108 Scharpf (n 91) 230.
} 
the Court's interpretation of what counts as minimum pay under the Directive, some States were required to do nothing, whilst others had to undertake a 'genuinely radical restructuring of [the] collective bargain system'. ${ }^{109}$ Once a national measure falls outside the scope of the Directive, it seems almost impossible that it can be justified. This was the case in Laval and Rüffert, as national measures could not be justified on the basis of Article 56 TFEU, and was also the case in Commission v Luxembourg in the context of the public policy exception under Article 3(10) of the Directive. The inability to find consensus among the Member States showed the difficulties in re-regulating social policy at the European level, with its legal bases being solely the service and establishment provisions directly due to the QMV requirements, rather than unanimity, within the Council.

\subsection{Market bias within the Directive}

It is a common critique of the Court that when confronted with a situation in which it must balance the interests of the market with the social, it will almost invariably put the rights of business and enterprise above those of, for example, workers. Those who would prefer a stronger social dimension within the process of European integration often find themselves disappointed by the Court's decisions, and the value it places on the 'social' within the EU legal order. In terms of posted workers, surprisingly little emphasis is placed on enforcing the rights of workers themselves, let along the effect on domestic workers. Cases tend to be framed around the ability of Member States to extend their domestic regulation to posted workers themselves, rather than posted workers being given the right to equal treatment with domestic workers. ${ }^{110}$ This has led to a situation where it was not even certain that the rights and protections that were conferred on posted workers could be invoked by the workers themselves.

As has already been explained, the entire concept of posted work owes much to the specific legal rules applying to Portuguese service providers and their workers during the transitional period of the accession of the Southern Member States. Moreover, the decision to adopt the Directive solely on the basis of the services and establishment provisions was taken predominantly in order to get the legislation through the Council by circumventing unanimity requirements, and after a number of failed legislative attempts. This set the conditions for the Directive to be skewed towards the market rights of services providers rather than the social

\footnotetext{
109 Kilpatrick (n 60) 853-854.

110 Davies (n 25) 590.
} 
rights of workers. The sole use of service and establishment provisions as legal bases to the Directive was contrary to the expectations of labour lawyers, who had widely assumed that the Directive would be based on protecting workers, rather than being a measure to facilitate freedom to provide services. ${ }^{111}$ Currently, the Directive makes no reference not just to the free movement of workers, but also to any social policy provisions of the Treaties. This means that posted workers are not entitled to the expansive reach of the non-discrimination principle that applies to workers, and which protects not just migrant workers themselves, but also the workers of that Member State against migrant workers that are willing to work for lower wages and social conditions. ${ }^{112}$ Furthermore, the obligation in Article 152 TFEU to promote workers' standards of living and working conditions does not apply to service providers and their posted workers. As there is no 'constitutional basis' for raising the employment standards of these workers, any application of national labour legislation is therefore regarded as an obstacle to the service provider. ${ }^{113}$ These persons become a mere factor of production - a commodity whose human value is secondary to the economic interests of their employer, the foreign service provider.

In this context, and whilst the Directive is nominally supposed to strike a balance between the interests of employers, posted workers, and host-State employees in a way which legitimises the posting of workers and facilitating the cross-border supply of services, it could be suggested that the Court will inevitably interpret provisions of the Directive like Article 3(1) with a pro-market stance. When making its decisions, the Court simply has no social factors to consider. That being said, the Court could have interpreted the Directive in a way to allow a variety of state practices above the floor of mandatory protections. This is suggested to be an interpretation consistent with the widely accepted understanding of other directives and regulations, which do not seek to set out either uniform laws or even a level playing field, but to establish a floor of rights above which regulatory competition is possible. ${ }^{114}$ However, the background to Article 3(1) shows that it is probably best understood as a conflict of laws instrument that derogates from the country-of-origin principle, rather than as an instrument laying down minimum standards. That being said, the Directive is at least intended to confer labour law rights and the benefits of collective agreements upon posted workers, rather than removing such protections. ${ }^{115}$

\footnotetext{
111 Barnard (n 72) 126.

112 Schiek (n 24) 355

113 Verschueren (n 12) 136.

114 Deakin (n 52) 14-16.

115 ibid.
} 


\section{Revising the Posted Workers Directive}

After being proposed in 2016, the Revision to the Directive has gone through a complicated adoption process. Ten Member State Parliaments, mainly from Eastern Europe (with the exception of Denmark), criticised the proposal using the yellow card procedure. In particular, they claimed the principle of 'equal work for equal pay in the same place', as well as the introduction of the concept of 'remuneration' in the Directive, would remove their competitive advantage. There was also predictably much wrangling between the Council members as various Member States tried to further their own interests, as well as between the Council and Parliament. Despite this, the final text for the Revision was adopted in June 2018 and the Revised Directive came into force in July. This final section will examine: the Revision to the Directive in detail, looking at why it was proposed; the key changes to the text, in particular relating to remuneration; and its likely effects in terms of the issues arising from the Court's case law, as well as the more fundamental issues outlined in the previous section.

\subsection{Justifying the Revision}

Whilst the problems arising from the Court's acquis were recognised, it was considered that these could most adequately be dealt with through enhanced enforcement, rather than revising the legislation as such. ${ }^{116}$ In this respect, Directive 2014/67 on the enforcement of Directive 96/71/ EC concerning the posting of workers was adopted. ${ }^{117}$ Additionally, the Court strictly enforced the Directive in cases of fraud and abuse. It held that national courts may disregard social security certificates issued fraudulently to posted workers, ${ }^{118}$ and found that whilst a national requirement to send prior declaration of postings violated Article 56 TFEU, a requirement to keep copies of documents 'equivalent to social or labour documents required under national law' was permitted. ${ }^{119}$ The Court has more recently sought to clarify Article 3(1) of the Directive. It has held that minimum pay can be divided into separate pay groups, depending on the categorisation of employees, so long as its calculation is 'binding and transparent'. Furthermore, a daily allowance, compensation for

\footnotetext{
116 European Commission Impact Assessment, Revision of the legislative framework on the posting of workers in the context of the provision of services accompanying the document Proposal on the enforcement of Directive 96/71/EC concerning the posting of workers $\operatorname{SWD}(2012) 63$ final.

117 Directive 2014/67/EU of the European Parliament and of the Council of 15 May 2014 on the enforcement of Directive 96/71/EC concerning the posting of workers in the framework of the provision of services and amending Regulation (EU) No 1024/2012 on administrative cooperation through the Internal Market Information System [2012] OJ L159/11.

118 Case C-359/16 Ömer Altun ECLI:EU:C:2018:63.

119 Case C-515/08 Vitor Manuel dos Santos Palhota ECLI:EU:C:2010:589.
} 
daily travelling time, and annual holiday had to be included within the concept of the minimum rate of pay under Article 3(1), although accommodation and meal vouchers did not. ${ }^{120}$ It has also held that in order to meet the definition of 'hiring-out' under the Directive, the movement of posted workers must be for the 'very purpose of the supply of services'. ${ }^{121}$ The Court has also held that if an employer requires the worker to carry out additional work, or work 'under particular conditions', this must be compensated for but does not need to be taken into account when calculating the 'minimum rate of pay' under the Directive. ${ }^{122}$

Despite these modest developments, it was considered necessary 'after 20 years' to reassess the balance between promoting the freedom to provide services and ensuring fair competition, with the need to protect the rights of posted workers. ${ }^{123}$ Empirical evidence suggests that criticism of the posted workers' regime is well founded. Initially it is worth highlighting the stark differences in labour costs throughout the European Union. Eurostat data indicate that whilst the costs of an average hour of work for employers (including pay and non-wage costs like social security contributions, etc) are around $€ 40-€ 42$ in States such as Denmark and Belgium, in Romania and Bulgaria the costs are around $€ 5$ per hour. ${ }^{124}$ In fact, already in 2012 the Commission recognised that the Directive "puts pressure on local labour markets and working conditions in particular in high unemployment regions', ${ }^{125}$ even if it considered that this could be fixed through better enforcement rather than amending the legislation. However, in its more recent Impact Assessment for the revised Directive, the Commission was more assertive: "posted workers are reported to receive lower remuneration than local workers, especially in high-wage receiving countries'. The Commission also indicated that - even when complying with the Directive - wages for posted workers were on average $10 \%-15 \%$ lower in the Danish construction industry, $25 \%-35 \%$ lower in the Dutch construction industry, and up to $50 \%$ lower in the Belgian road transport sector. ${ }^{126}$ More problematic is that in some jurisdictions posted workers are only entitled to the minimum legislated wage in that State, regardless of the going rate for a particular

\footnotetext{
120 Case C-396/13 Sähköalojen ammattiliitto ry ECLI:EU:C:2015:86.

121 Case C586/13 Martin Meat kft ECLI:EU:C:2015:405.

122 Case C522/12 Tevfik Isbir ECLI:EU:C:2013:711; see also Case C-341/02 Commission v Germany ECLI:EU:C:2005:220.

123 Directive 2018/957, Recital 4.

124 See Eurostat, Wages and Labour Costs (2017) available at <https://ec.europa.eu/ eurostat/statistics-explained/index.php/Wages_and_labour_costs\#Main_statistical_findings $>$ accessed 17 December 2018.

125 European Commission Impact Assessment (n 116) 23.

126 European Commission Impact Assessment (n 5) 13.
} 
job. In the UK, posted workers generally receive just $40 \%$ of the average wage, whilst in more protective States, such as Sweden and Denmark, posted workers receive only $70 \%$ of the average wage. This led the Commission to conclude that the Directive "can exert downward wage and overall labour cost competition on local companies and workers in highwage Member States'. ${ }^{127}$ The effects of these differences should not be overlooked or trivialised. Even a small difference in wage rates between domestic and foreign service providers is likely to have a significant effect on the behaviour of undertakings and governments. Domestic undertakings will need to regain competitiveness, which will most likely be done through a reduction in their own labour costs, or by lobbying state actors to reduce national standards (under the guise of 'flexibility' and 'competitiveness') to level the playing field. It should also be noted that it is not just the high-wage countries that are liable to suffer from this vicious circle. Posted workers may not cause low-wage countries to actively reduce their standards even further, but they give them no incentive to increase their standards or to 'catch up' with high-wage States. This problem will be exacerbated if the receiving States in turn reduce their own standards, possibly contributing to a race-to-the-bottom.

\subsection{The Revised Directive and the new rules on remuneration}

Perhaps unsurprisingly, given the controversy within the Council over the term, the principle of 'equal pay for equal work in the same place' does not appear in the final text of the Directive. That being said, it does make an explicit link between the principles of 'equal treatment' and 'equal pay', which has been implemented through secondary law, not only between women and men, but also between fixed-term and permanent workers, part-time and full-time workers, and temporary and permanent workers. ${ }^{128}$ Equal pay generally has a long history in the Treaties: Article 157 TFEU states that Member States shall ensure the principle of equal pay for male and female workers for equal work or work of equal value is applied. ${ }^{129}$ The Directive is not so explicit in its language, but it clearly places more weight on the idea of equal treatment and equal pay between posted and native workers. Equal treatment in terms of equal pay between posted workers and domestic workers in the same location is a guiding principle of the Revised Directive, although the Commission rejected some of the more far-reaching ideas to ensure equal pay, such as using a reference undertaking. ${ }^{130}$

\footnotetext{
127 European Commission Impact Assessment (n 5) 12-14.

128 Directive 2018/957 (n 9) Recital 6.

130 European Commission Impact Assessment (n 5) 27.
} 
In respect to Article 3 of the Revised Directive, the concrete changes to the final text are not extensive, although they were in fact the most radical of the options considered by the Commission. Other options involved more 'clarification' on the rules on minimum rates of pay by the Court of Justice, rather than new legislation. ${ }^{131}$ As well as the rules on remuneration, the Directive will also legislate for long-term posting. For postings longer than 12 months, the host Member States should guarantee the 'terms and conditions of employment that are mandatorily applicable to workers in the Member State where the work is carried out'. ${ }^{132}$ The principle of equal pay is explicitly mentioned, ${ }^{133}$ and the Directive also focuses specifically on agency workers, as the principle of equal pay enshrined in Directive 2008/104/EC should apply to temporary agency workers posted to the territory of another Member State.

For our purposes, in the context of rates of pay under Article 3(1)(c), this has changed from 'minimum rates of pay' to 'remuneration, including overtime rates'. This is explained in more detail within Article 3(1):

remuneration means all the elements of remuneration rendered mandatory by national law, regulation or administrative provision, collective agreements or arbitration awards which have been declared universally applicable and/or, in the absence of a system for declaring collective agreements or arbitration awards to be of universal application, other collective agreements or arbitration awards within the meaning of paragraph 8 second subparagraph, in the Member State to whose territory the worker is posted.

During discussions in the Council, this was amended to 'the concept of remuneration shall be determined by the national law and / or practice of the Member State', ${ }^{134}$ in a move which places even more emphasis on national systems of wage setting. In this regard, Recital 17 specifically states that 'the setting of wages is a matter for the Member States and the social partners alone. Particular care should be taken not to undermine national systems of wage setting or the freedom of the parties concerned'. This was again included by the Council, as it emphasised that this should include 'but should not be limited to, all the elements of

\footnotetext{
131 ibid, 22.

132 Directive 2018/957 (n 9) Recital 9; see also Council of European Union, Proposal for Directive on Posting of Workers - Analysis of the final compromise text with a view to agreement (28 March 2018) 7350/18, 6. Under Directive 2018/957, Art 3(1)(a), this can be extended by an additional 6 months.

133 Directive 2018/957, Recital 6; Council of European Union, Proposal for Directive on Posting of Workers - Analysis of the final compromise text with a view to agreement, Recital 7; see also Proposal for a Directive (n 4) Recital 5.

134 Council of the European Union, General Approach to the Proposal for a Revision amending the Posted Workers Directive 13612/17, 11-12.
} 
minimum rates of pay developed by the Court of Justice of the European Union'. ${ }^{135}$ Furthermore, the total gross amounts of remuneration should be compared, rather than individual elements of remuneration rendered mandatory as provided for in Article 3(1). ${ }^{136}$ Recitals 17 and 18 explicitly state that all gross earnings and additional allowances should be considered within the concept of remuneration, instructions which also make their way into Article 3. It should also be noted that allowances are included under the Directive under Article 3(1)(i). Recital 8 clarifies that posted workers should receive 'at least the same allowances or reimbursement of expenditure to cover travel, board and lodging expenses' as are applicable to local workers. This should apply to the expenditure incurred by posted workers required to travel to and from their regular place of work. However, it is noted that 'double payments' of travel, board and lodging expenses should be avoided. Whilst the actual wording has changed little, there is more indication of what the changes mean in the recital to the Proposed Directive.

\subsection{The effects of the revision}

Providing more discretion to Member States to ensure a level playing field between service providers in their territory, particularly in regard to remuneration, is clearly the guiding objective of the Directive, and it will certainly provide more discretion in this regard. In fact, in a number of ways, for example the definition of remuneration, the emphasis on national systems of wage setting, and the reduction of the threshold before a posting is 'long-term', the final text goes even further than the Commission's 2016 proposal. Specific to the concept of remuneration, the Directive is much clearer: this encompasses all gross pay and associated allowances and benefits, as well as the prerogative of Member States to set up their systems of wage negations and industrial relations, in what is clearly an attempt to avoid another Laval situation. That being said, the precise legal value of the changes will depend greatly on the Court's approach to interpreting the Revised Directive in future cases, and the extent to which it 'rebalances' the protection of workers against those of service providers. The following section will assess the extent to which this will happen, looking at both the acquis of the Court and the wider problems outlined in the previous section.

135 ibid, 6.

136 ibid. 


\subsubsection{The Court's case law}

It is probably the case that the Revision to the Directive is directed primarily at the Laval decision. Under the new Directive, the concept of 'remuneration' would cover the Swedish trade union's imposition of a 16 per hour wage in additional to other benefits and allowances. Given the extensive explanation of the term 'remuneration' within the Revision, it would be impossible to interpret this as being outside the scope of Article 3(1). That being said, the question over the actual action a social partner can take to enforce such wage demands, even if they fall under Article 3(1), still remains. However, interestingly, the references included within the Proposal for a Revised Directive to the caveat that the application on rules on remuneration 'must not disproportionately restrict the cross-border provision of services' ${ }^{\prime 37}$ have all been removed in the final text of the Directive. Instead, the Directive emphasises the need not to undermine national systems of wage settings as well as to protect the diversity of national industrial relations, ${ }^{138}$ as will likely be the case in situations like Laval where there is no legislated applicable rate of pay. Having said this, it should be noted that the Revision to the Directive does very little to change how measures are justified under the public policy provision in Article 3(10) of the Directive, as well as the extent (if any) to which measures falling outside the scope of Article 3(1) can be justified under Article 56 TFEU.

The Rüffert decision is more problematic. There have not been significant changes to Article 3(8) of the Directive, apart from it being extended to all sectors of the economy, which will obviously allow for more collective agreements to be covered under the Directive. ${ }^{139}$ Whilst the new rules and emphasis on national systems of wage setting will certainly allow for more types of collective agreements to be enforced under the Directive, it is not clear that a local authority can impose collectively agreed wages that are higher than collective agreements or legislated wages applicable in the private sector. Concretely, it is still unclear whether the private/public sector discrimination distinction still applies, or whether such measures (for example, the pursuit of a non-binding 'living wage') would justify such a measure.

There is also the question of whether the introduction of the 2004 and 2014 Public Procurement Directives have made the Rüffert decision redundant. It is true that the 2004 and particularly the 2014 Directive

\footnotetext{
137 Proposal for a Directive (n 4) Recital 12.

138 Directive 957/2018 (n 9) Recital 24.

139 Proposal for a Directive (n 4) 7; see also Directive 2018/957 (n 9) Art. 3(1), in which the sentence contained in Directive 96/71/EC, Art. 3(1) which ensures its application was solely to 'activities referred to in the Annex' has been removed.
} 
have more focus on the social considerations that can be included within public tenders. ${ }^{140}$ In the wake of the Court's decision in Regiopost, some (including this author) were quick to suggest that Member States could now demand higher rates than are legislated for when tendering out public services. ${ }^{141}$ However, this conclusion may have been too hastily reached. It should be emphasised that in Regiopost the Court did not distance itself from its previous Rüffert decision, or indeed discuss the extent to which it was decided that way due to the lack of applicable Public Procurement Directives at the time. Instead, the Court sought to differentiate the factual circumstances between the two cases. ${ }^{142}$ According to the Court, Rüffert concerned a 'collective agreement applying solely to the construction sector, which did not cover private contracts and had not been declared universally applicable' which 'exceeded the minimum rate of pay applicable to that sector under the AEntG (Posted Workers Law)'. ${ }^{143}$ This approach was confirmed in Bundesruckerei, when it was held that social considerations under the Public Procurement Directive 'may be imposed only to the extent to which they are compatible with Community law'. ${ }^{144}$ Therefore, social considerations that imposed wage demands in public tenders that go beyond minimum rates of pay constitute 'an additional burden that may prohibit, impede, or render less attractive the provision of services in the host Member State'. ${ }^{145}$ The Court repeated the private/public discrimination principle, suggesting that such a measure is not appropriate for the aim of avoiding social dumping as it cannot be said that employees working in the private sector were not in need of the 'same wage protection as those in the context of public contracts. ${ }^{146}$ On the other hand, in Regiopost the minimum rate of pay was legislated for in law, and applied generally to the award of any public contract in the Rhineland-Palatinate 'irrespective of the sector concerned'. ${ }^{147}$ The Court went even further, suggesting that at the time of the facts, there was no legislated minimum wage applicable to the postal

\footnotetext{
140 See Directive 2014/24/EU of the European Parliament and of the Council of 26 February 2014 on public procurement and repealing Directive 2004/18/EC [2014] OJ L94/65, Art 18; Directive 2004/18/EC of the European Parliament and of the Council of 31 March 2004 on the coordination of procedures for the award of public works contracts, public supply contracts and public service contracts [2004] OJ L134/114, Art 26.

141 See, for example, Daniel Carter 'CJEU (Finally) Takes Stance against Social Dumping' (Leiden Law Blog, February 2016) available at <https://leidenlawblog.nl/articles/cjeu-finally-takes-stance-against-social-dumping> accessed 23 December 2018.

142 See Case C115/14 Regiopost ECLI:EU:C:2015:760, paras 73-75.

143 ibid, para 74 .

144 Case C-549/13 Bundesdruckerei ECLI:EU:C:2014:2235, para 28.

145 ibid, para 30.

146 ibid, paras 31-32.

147 Regiopost (n 142) para 75.
} 
sector, and as such the rates demanded of the tenders was indeed the 'minimum social protection' (in a curious deviation from its approach in Laval). ${ }^{148}$ Therefore, Regiopost would not seem to overturn Rüffert, even in the light of the Public Procurement Directive. Indeed, it is 'almost certainly not the case' whether it really allows contracting authorities to impose social conditions which exceed those laid down in national legislation. ${ }^{149}$

\subsubsection{Wage competition and social dumping}

In the previous section it was concluded that the use of differing regulatory obligations between Member States, specifically when foreign service providers are able to compete unfairly on a national market by circumventing national wage demands in order to gain a competitive advantage, strays beyond the normal use of internal market rules and into the area of unfair competition that can undercut local competitors and place pressures on domestic workers' wages. At least in the context of posted work, this should be seen as constituting 'social dumping'. The shift from minimum pay to remuneration, as well as the new rules on employment agency postings and allowances, will likely mitigate the most negative effects of the current posted workers' regime. Moreover, there is less focus on competition on the basis of wages and labour costs in the Revised Directive. In its Impact Assessment, the European Commission finally recognised that wage competition can have significant negative effects on wage rates and foster an environment of unfair competition, at least when undertakings can use diverging regulatory regimes in order to pay less than domestic rivals. That being said, it was still included in the proposal that competition based on labour costs is an important part of the internal market. ${ }^{150}$ Interestingly, however, by the time of the final text, 'labour costs' were removed from the list of factors of competition contained in the preamble to the Directive. ${ }^{151}$

The changes to remuneration will surely result in a more level playing field when service providers are competing within the same jurisdiction. In principle, Member States and their social partners will be able to demand that foreign service providers pay collectively agreed and even

\footnotetext{
148 ibid, para 76.

149 Joosje Hamilton and Ryan Brendan, 'Minimum Wage Special Conditions in Public Procurement Tender Processes: Regiopost $v$ Stadt Landau (Case C-115/14)' (February 2016) available at <www.nortonrosefulbright.com/knowledge/publications/136611/ minimum-wage-special-conditions-in-public-procurement-tender-processes-regiopost-v-stadt-landau-case-c-1151> 23 December 2018.

150 Proposal for a Directive (n 4) Recital 11.

151 Directive 2018/957 (n 9) Recital 16
} 
case-by-case negotiated wage rates. The Directive now makes reference not just to laws and collective agreements, but also to the practice of Member States. As such, the regulatory gap that allowed such disparities in terms of wage obligations existing for domestic and foreign service providers (and even changes in the applicable law) that arose from the Laval judgment will be closed.

However, this does not totally exclude wage competition from the process, particularly if we consider the idea of remuneration or labour costs in the wider sense. As has already been mentioned, in Rüffert an infringement was found precisely because the undertaking would 'lose the competitive advantage which they enjoy by reason of their lower wage costs'. ${ }^{152}$ Nothing suggests that this is no longer the case. It is also unclear whether local authorities can make wage demands in procurement tenders that would bind domestic service providers but which cannot be applied to foreign ones. If so, then the use of diverging regulatory jurisdictions may still significantly undermine the core objective of the Directive. Whilst not related to remuneration strictu sensu, the Revised Directive does nothing to change the rules of social security payments. As these are based on the host-State legislation, there remains a sharp division between the obligations applying domestic and foreign service providers. As explained previously, employer costs per worker can range from around 40 per hour in Belgium and Denmark, to around 3-4 in Romania and Bulgaria. This still offers a significant advantage for foreign service providers in terms of their labour costs in the wider sense, even if not remuneration in the simple sense. That being said, the final text dictates that long-term postings (ie postings that last more than $12 / 18$ months) be subject to the host-State legislation, meaning they will be fully embedded in the society of the host State, at least to the same extent as regular workers under Article 45 TFEU. Whilst competition on the basis of wages and labour costs will not be entirely removed from the use of posted workers within the system of service provision in the European Union, the Revised Directive certainly looks likely to mitigate some of the most damaging effects of the Court's approach to interpreting the Directive.

\subsubsection{Posted workers and deregulation}

In the previous section it was explained how the original Posted Worker Directive was effectively applied as a tool of deregulation. Rather than re-regulating at the European level towards a more socially inclined system, the Directive actually took the more deregulatory aspects of the

152 Ruffert (n 2) para 14. 
pre-Directive acquis and rejected some of the more protective principles as espoused by the Court of Justice. ${ }^{153}$ Rather than enforcing minimum standards, decisions such as Laval and Rüffert have been essentially an opportunity for undertakings to challenge Member State practices that go above minimum pay obligations. Moreover, the inability of Member States to justify such national measures means the Directive has served to deregulate some Member State systems of wage setting, and pushed Member States towards a 'European' Liberal Model, thereby undermining any CME's higher labour standards and collective agreements. This can be evidenced by the fact that the more CME-inclined States were the most aggrieved by the current situation. The Revised Directive will better ensure this diversity by extending the rules on collective agreements to all sectors of the economy, which, when combined with the shift from a minimum rate of pay to total remuneration, will go some way to combatting the deregulatory nature of the Directive. Overall, there is surely more flexibility offered to Member States that seek to pursue more CME policies. Certainly, it seems that CMEs would not have to change their laws in order to accommodate decisions of the Court such as Laval.

Whilst there was clearly difficulty in finding consensus within the Council, this was not, as Scharpf's theory might suggest, fatal to the Directive's chances of being adopted. There was not just disagreement between LME and CME States that are ideologically opposed, but also between older high-wage States and the newer low-wage States, the latter of which stood to gain from the current system (and notwithstanding any ideological opposition). On the face of it, this seems to have been achieved without excessively watering down the changes to the Directive, which is surprising given the extent to which it potentially removes the competitive advantage of foreign service providers. If anything, during trilogue discussions the Directive has arguably become more protective of national systems of wage setting and industrial relations. The episode should offer encouragement to those adhering to Scharpf's pessimistic view of re-regulation at the European level.

That being said, there are certain deregulatory aspects of the Directive that may remain. Despite the emphasis on remuneration, rather than minimum pay, Article 3(1) still sets minimum and maximum standards that Member States are not permitted to go beyond. It is unclear to what extent Member States can make demands of all undertakings (both foreign and domestic) if these go beyond rates of pay that are 'universally' applicable under the Directive. For example, it is unclear whether the private/public sector distinction exists and whether a Member State can demand that undertakings commit to pay higher wages in public sector

153 Verschueren (n 12). 
contracts. Finally, even when national measures fall outside the scope of the Directive, there are very limited justifications on which the Member State can rely, either through Article 56 TFEU or relying directly on the public policy exception included within the Directive. It seems unlikely that the Revised Directive will change anything in this regard. That being said, earlier statements indicating that rules on remuneration must not disproportionately restrict the cross-border provision of services were removed from the final text of the Revised Directive. ${ }^{154}$ The Directive now only includes a generic reference to the fact that restrictions to the freedom to provide services are allowed 'only if they are justified by overriding reasons in the public interest and if they are proportionate and necessary'. ${ }^{155}$ Despite the improved rhetoric in the preamble, it is unlikely that there will be concrete changes to the justifications of measures that go beyond the rules in Article 3(1).

\subsubsection{Market bias in the Revised Directive}

This paper has made the suggestion that the 'market bias' of the Directive, ie that it is adopted using solely the provisions on services and establishment, ensures that when confronted by ambiguously worded provisions, such as Article 3(1) of the current Directive, the Court of Justice inevitably opts for a more (or arguably the most) pro-market interpretation. In the context of posted workers, the Advocates General in Laval, Rüffert and Commission $v$ Luxembourg all came to different conclusions from the Court, often using entirely different approaches to do so. It is clear that Article 3(1) of the Revised Directive is much less ambiguous than the previous wording of the provision. As such, it offers much less scope for interpretation by the Court. The Directive includes rules on what benefits and allowances should be included within the concept of remuneration under the Directive. More generally speaking, at least in the preamble to the Revised Directive, there is also more focus on the position of the posted workers themselves, rather than solely service providers. The Directive makes clear that there is a need to reassess the balance struck between promoting the free movement of services and the need to protect workers, ${ }^{156}$ and makes more reference to the protection of the posted workers themselves, particularly in terms of pay. ${ }^{157}$ There is also reference to the Union goal of promoting social justice and protec-

\footnotetext{
154 See Proposal for a Directive (n 4) Recitals 12 \& 13.

155 Directive 2018/957, Recital 10.

156 Directive 2018/957, Recital 4.

157 See, inter alia, Directive 2018/957, Recitals 10 \& 24. See also European Parliament and Council Agreed Position, Directive of the European Parliament and of the Council amending Directive 96/71/EC concerning the posting of workers in the framework of the provision of services (14th June 2018) 2016/0070 (COD) PE-CONS 18/18.
} 
tion, as well as its obligation under Article 9 TFEU to 'take into account' requirements relating to high employment, social protection, combatting social exclusion, education, training, and human health. ${ }^{158}$

However, despite the overtures contained within the preamble, it is still based solely on the provisions on establishment and services. Whist this is understandable, given the Directive's status as a revision to a Directive, which was based on these Treaty freedoms, as has been explained before, this was predominantly the result of the free movement of workers provisions not applying to Portuguese undertakings during the transitional period in the Southern Accession Member States, as well as the inability to find unanimity within the Council. The Directive has not been updated to be additionally based on workers or social policy provisions in the Treaties, despite the increased mention of worker protection and other social elements of European integration in the Revised Directive.

Therefore, despite the fact that Article 3(1) of the Revised Directive is much less ambiguous than the previous wording of the provision and the term remuneration being accompanied by extensive explanations, as well as the more worker friendly language in the preamble, the Directive is still skewed towards establishment and services without reference to the free movement of workers or the Treaty's social provisions. Despite removing most of the previous ambiguities of Article 3(1), some will inevitably remain. Whilst the rules on remuneration strictu sensu may be clearer, uncertainties will remain in relation to wider benefits, cash or otherwise, related to employment or labour standards generally. Furthermore, the Court will likely have to interpret the scope of the new rules on agency workers and short-term postings. Much will therefore depend on the Court's approach in future cases, and in particular the extent to which it re-balances the system of posted work in the EU away from service providers and towards the protection of workers.

\section{Conclusion}

The process of adopting the Revised Directive, with its guiding aim of 'equal pay for equal work in the same place', indicates clear recognition that the system of posted work as it currently functions has the potential to undermine local wages and employment conditions, thereby fostering unfair competition and social dumping. Analysis of previous decisions of the Court of Justice, along with empirical evidence, puts this beyond dispute. Given the vastly divergent interests at stake, it is commendable that the Revised Directive was adopted at all. Encouragingly, the Direc-

158 Directive 2018/957, Recital 3. See also Article 3 TEU and Article 9 TFEU. 
tive has been adopted without the main changes, in particular the provisions of remuneration, being watered down excessively. If anything, the opposite seems to have been the case during the adoption process. In the final text of the Directive, there is strong emphasis on ensuring parity of pay between posted and domestic workers, as well as the protection of workers themselves. Moreover, the Directive will apply to a broader range of situations and it takes into greater consideration national systems of wage setting and industrial relations.

The Revised Directive should go some way to rectifying the problems caused by the Court's approach to interpreting the Directive, in particular the Laval decision. That being said, it is unclear to what extent the Member States can go beyond the conditions laid down in Article 3(1), particularly in cases concerning public procurement. More fundamentally, the principle of 'equal pay for equal work in the same place' seeks to strike a new normative balance between the concepts of wage competition and social dumping. The new Directive also goes some way towards countering the pessimistic hypothesis of Scharpf, given that there was an agreement found despite the parties' conflicting interests, as well as the fact that the Revised Directive will (or at least should) provide more flexibility in terms of coordinated market economies' ability to enforce their labour laws, for example in a Laval-type situation. Lastly, the legal bases of the Directive have not changed, meaning the Directive is still not based on any of the social provisions in the Treaties.

The transposition date for the new Directive is not until 30 July 2020, and therefore we may not see any concrete changes to the posted workers' regime until that point. Of course, much will depend on the attitude of the Court to cases concerning posted workers, and the emphasis it places on striking a new balance between the interests of service providers and workers. It will take a shift in attitude and approach from the Court to overcome the Directive's in-built market logic and deregulatory effects. When considering the precise scope and value of the Revised Directive, the Court would do well to consider the concluding passage of Barnard back in 2012, which seems even more pertinent now than it was back then: European integration will collapse if ordinary Europeans feel it is about little more than open markets. Without a strong social dimension the project is doomed to fail. The historic bargain between the interests of open markets and workers and trade unions has served the continent well for decades, and is one we abandon at our peril. ${ }^{159}$

159 Barnard (n 56) 135, referencing the words of ex-Trade Union Congress Chairman Brendan Barber. 